\title{
Gradually Increased Interhemispheric Functional Connectivity During One Night of Sleep Deprivation [Corrigendum]
}

Zhu Y, Ren F, Zhu Y, et al. Nat Sci Sleep. 2020;12:1067-1074. The authors apologize for this error.

The authors have advised that the name of last author on page 1067 is incorrect. Mingwen Zheng should be Minwen Zheng.

Nature and Science of Sleep is an international, peer-reviewed, open access journal covering all aspects of sleep science and sleep medicine, including the neurophysiology and functions of sleep, the genetics of sleep, sleep and society, biological rhythms, dreaming, sleep disorders and therapy, and strategies to optimize healthy sleep.
The manuscript management system is completely online and includes a very quick and fair peer-review system, which is all easy to use. Visit http://www.dovepress.com/testimonials.php to read real quotes from published authors. 